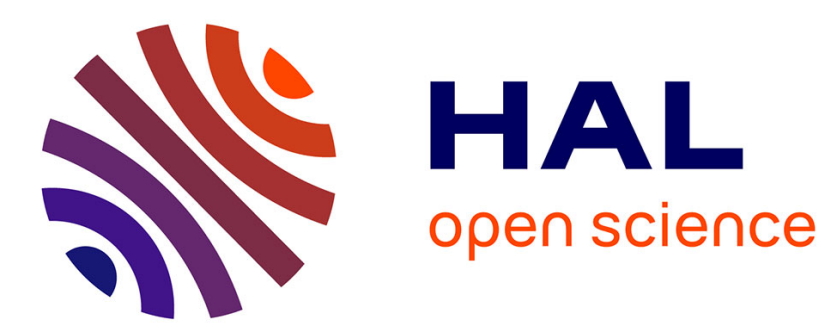

\title{
Proposition on the Theory of Policing
}

Fabien Jobard

\section{To cite this version:}

Fabien Jobard. Proposition on the Theory of Policing. Penal Field, 2012, IX, http://champpenal.revues.org/8286. hal-00744208

\section{HAL Id: hal-00744208 \\ https://hal.science/hal-00744208}

Submitted on 22 Oct 2012

HAL is a multi-disciplinary open access archive for the deposit and dissemination of scientific research documents, whether they are published or not. The documents may come from teaching and research institutions in France or abroad, or from public or private research centers.
L'archive ouverte pluridisciplinaire HAL, est destinée au dépôt et à la diffusion de documents scientifiques de niveau recherche, publiés ou non, émanant des établissements d'enseignement et de recherche français ou étrangers, des laboratoires publics ou privés. 


\title{
Champ pénal/Penal field
}

Nouvelle revue internationale de criminologie

\author{
Vol. IX | 2012 :
}

Varia

Actes de colloque/Conference Proceedings - L'œuvre singulière d'un penseur cosmopolite : Hommages à Jean-Paul Brodeur

\section{Proposition on the theory of policing}

\author{
FABIEN JOBARD
}

\section{Résumés}

Cet article revient sur les débats que Jean-Paul Brodeur avait développés durant au moins deux décennies autour de la place de la force dans la définition et la théorie de la police. L'auteur expose d'abord le projet théorique de The Policing Web, son dernier ouvrage, et la place qu'occupe dans celui-ci « l'illégalisme policier », qui constitue la pierre fondatrice de la théorie de la police avancée par Jean-Paul Brodeur. Il esquisse ensuite une approche sociologique de cet illégalisme policier, en montrant pour quelles raisons la méthode retenue par Jean-Paul Brodeur ne pouvait être qualifiée de sociologique, avant de formuler une " théorie sociologique de la police », fondée sur la notion de souveraineté. L'emploi de cette notion le conduit à préciser son acception, avant de formuler une proposition de « théorie politique de la police».

This article revisits several arguments that Jean-Paul Brodeur developed for at least two decades on the role of the use of force in the definition and a general theory of policing. The author examines the theoretical project that characterizes The Policing Web, his last book, and assesses where "legal lawlessness", the touchstone of the theory of policing put forward in the book, fits. He then outlines a sociological approach of legal lawlessness, considering that Jean-Paul Brodeur's chosen method could not be considered a sociological one. At that point, a "sociological theory of policing" will emerge, based on the concept of sovereignty. After having clearly defined this concept's accepted meaning, a "political theory of policing” is formulated.

\section{Entrées d'index}

Index de mots-clés : Jean-Paul Brodeur, force, illégalisme policier, souveraineté, théorie de la police, violence policière

Index by keyword : Jean-Paul Brodeur, force, police legal lawlessness, police violence, sovereignty, theory of policing

\section{Notes de la rédaction}

Traduction : François-Xavier Priour

\section{Texte intégral}




\section{Introduction}

This contribution is an (obviously rather sad) opportunity to revisit at least two decades of discussions developed by Jean-Paul Brodeur with a view to assign force its proper place in the definition and theory of policing. As evidenced by various publications ${ }^{1}$, such debates regularly brought us together, and it will be only too natural for my tribute to tackle the issue of police brutality once again - at a time when, as it tends to happen, various unrelated cases have recently put the use of force by French policing authorities in the spotlight ${ }^{2}$.

2 Jean-Paul Brodeur, in his posthumous work The Policing Web, thoroughly re-examined the importance of physical force in policing action, especially in chapter 4, which covers the theory of policing. The whole purpose of this chapter is to refute and then amend Egon Bittner's PUFP (Police Use of Force Paradigm). Let us keep in mind, though, that in the 2008 book commemorating French police sociologist Dominique Monjardet, who passed away in 2006, Brodeur had considered that this matter - physical force in the definition of policing - had been given too much importance (Brodeur, 2008a). I shall therefore take Jean-Paul's warning as a preterition, and for what it actually is, i.e. an invitation.

3 I shall honor this invitation first by introducing the theoretical aim of Policing Web and assessing where "legal lawlessness"(lillégalisme policier ${ }^{3}$ ), the touchstone of the theory of policing put forward in the book, fits. I shall then outline a sociological approach of legal lawlessness, considering that, as I will try to demonstrate, Jean-Paul Brodeur's chosen method could not be considered a sociological one. At that point, a "sociological theory of policing" will emerge, based on the concept of sovereignty. Relying on this concept will compel us to clearly define its accepted meaning, before we formulate our proposed "political theory of policing", and conclude.

\section{Jean-Paul Brodeur: a new theoretical approach of policing}

In his treaty on policing (The Policing Web), Jean-Paul states that he is firmly determined to provide a new definition of policing and (to) introduce some of the elements of a theory of policing (6). His definition builds on the notion of legally using means prohibited to others (6). It is produced in the last pages of the chapter devoted to the theory of policing (chapter 4, 130):

\section{Policing agents are part of several connected organizations authorized to use in more or less controlled ways diverse means, generally prohibited by statute or regulation to the rest of the population, in order to enforce various types of rules and customs that promote a defined order in society, considered in its whole or in some of its parts.}

Strikingly, while one of Jean-Paul Brodeur's aspirations was to question "the nature of theory" (Policing Web, 7), the end product of his inquiry was a definition, not a theory; as if the main difficulty lay not so much in delivering a set of propositions derived from established observations as in embracing, in a single statement, both the specificity and scope of the policing institution. For the problem that Policing Web actually deals with is not in fact policing as a theoretical object pertaining to specific knowledge areas (social science, philosophy or others, which would turn policing theory into a sociological, political,... theory). Brodeur's problem, which he introduces as Policing Web's "challenge" (8), is the unity of police forces, which he considers to be challenged by the scattering and diversity that observers are initially confronted with when examining the institution and its agents. His 
definition involves an extensive use of plurals - "policing agents"4, " several connected organizations" - and is meant to embrace in its entirety the whole set of policing activities and statutes - from financial crime detectives to food safety officers to beat policemen, from law enforcement to intelligence.

Our reader might be surprised to realize, though, that Jean-Paul Brodeur considered his theory of policing as unsatisfactory, fraught as he felt it was by antinomies or discordances (...) that cannot be entirely resolved (Policing Web, 6).

The first such antinomy is to be found in the discordance between "openness" and "secret". While Brodeur was after a monistic theory of policing or, as he claimed in the first pages of Policing Web, a theory of police completeness (Policing Web, 9-10), he was confronted with a dual reality of policing. Policing, he argued, actually has two non-overlapping facets, one of which is open and the other secret ${ }^{5}$.

The second antinomy (which is specific to the theory of policing) rests on policing being a tainted occupation (Bittner, 2001/1974), insofar as policing work features some of the characteristics of its targets and is tainted by suspicion (2001, 302); a dark side that stands in stark contrast to the other facet of policing-a profession which, by essence, operates under a regime of legitimacy (Reiner, 1992), consent (Skogan, Frydl, 2004), or trust (Manning, 2003).

9 I shall argue here that the discordances mentioned by Jean-Paul are no discordances at all.

The circumstances that led him to posit these discordances (i.e. open/secret on the one hand, trust/hostility on the other) call for a sociological reassessment, which will enable us to rephrase Jean-Paul Brodeur's position. This rephrasing might be considered an attempt at formulating a sociological theory of legal lawlessness. As mentioned earlier, Brodeur's approach was not devoid of some ambiguity since, although his intention was to produce a "theory" of policing - a "monistic" theory of policing, even - he ended up with offering a mere definition of policing. In Social Theory and Social Structure, Merton considered that, in social sciences, a theory had to be a deductive set of logically interrelated propositions, such as for instance the production of revolutionary ideas stemming from a growing discrepancy between expected and actual salaries. Nothing of the kind with Brodeur, who restricted himself to defining his object, as opposed to a theory of this object. We argue, however, that it is precisely the lack of a theory that led him to consider these discordances as partially invalidating his own definition.

Our theoretical construct starts from where Jean-Paul had arrived: what defines or at least characterizes policing is its "legal lawlessness", i.e. the ability to legally infringe on the shared law. Beyond this common ground, everything sets us apart.

\section{The duality of social spaces and circumstances}

The legal lawlessness oxymoron refers to any infringement made on the shared law with a view to increase general respect thereof, e.g. driving down a one-way street the wrong way when trying to catch up with a runaway, or eavesdropping on private conversations using more or less sophisticated interception, wiretapping and recording devices, etc. ${ }^{6}$. Brodeur considered legal lawlessness as given by the law, inherent to any policing activity. The Canadian Code of criminal procedure, he observed, consists in an extensive inventory of all transgressions allowed to the police without fear of prosecution (Policing Web, 130-131).

What an empirical examination actually reveals is that, while inscribed in the letter 
of the code, legal lawlessness is by definition never set in stone: it is shifting, unstable, fragile, subject to recurring attacks from both society and magistrates, worried at the idea that some space they have no control upon is thriving quite apart from the regular normative order (what Jean-Paul dubs the "extra-legal" in Policing $W e b$ ). This is one instance (among others7) of the legal doctrine resorting to the concept of absolving excuse-always subject to in concreto appraisal from judges. In concreto: not in terms of any exegetical analysis of the Code, but after thoroughly examination of the concrete context of the policing intervention. Hence, the legal or illegal nature of policing lawlessness is first assessed by the courts, who decide to tip the scale either on the side of the shared law or in the gray area of legal lawlessness.

Proper understanding of the legal lawlessness allegedly enjoyed by policing agents thus entails examining actual decisions of magistrates regarding policing interventions they have been asked to adjudicate. What such an examination reveals is that lawlessness is only legal under certain conditions. My argument is that there exists a social space of legal lawlessness, which I shall explore succinctly.

Take for instance a 1991 policing intervention pitting a criminal investigation team from the greater Paris area against an alleged heroin dealer, M.Selmouni. This particular interaction ultimately led to the 1999 conviction of the French government by the European Court of Human Rights - on "torture" charges, which had only ever been pressed against the Turkish government until then (Uildriks, 1999; Rodey, 2005, 406). Even after this European-level verdict, however, the incriminated police merely received suspended prison sentences from the French courts (on this significant inconsistency, see Cahn, 2007). As for European judges, they considered that M. Selmouni, in addition to having been subjected to humiliating and degrading treatment, had been beaten during his four-day custody, which, still according to the European court, caused the loss of his left eye.

Upon reviewing this case, the French judges stated a rather interesting position:

Considering that the word of a police officer, especially a criminal investigator, is, in and of itself, more credible than that of a drug dealer; that, however, this postulate is weakened, if not shattered, whenever the criminals' statements are substantiated by external elements such as medical findings;

Considering that, not uninterestingly, [Madi and] Selmouni, never having been in police custody before, had no prior experience on which to rely upon to design an elaborate lie; that Selmouni received almost no legal advice throughout the drug trafficking proceedings; that taken as a whole, these factors persuade the Court that the alleged resistance to arrest was invented by the accused to justify the seriousness and location of the haematomas and the lesions found on the detainee [...]

What is legal lawlessness? This court decision may contribute to our understanding of it. Elements proving the wrongdoings are required by judges to successfully convert an allegation into a recorded fact (on this conversion, see Jobard, 2003). Material elements such as a medical certificates or statements by third-party witnesses, while extremely important to this certification process, are by no means sufficient ${ }^{8}$. Indeed, following the arguments put forward by the judges of the Paris appeal court in 1999, to these external conditions the putative victim needs to add one that pertains to its own constitution: the victim can only be credible if he/she does not belong to the "usual suspect" category, the police property mentioned by Lee (1981) in his seminal paper. It can even be said that the successful conversion of the allegation into a recorded fact rests on "penal virginity" itself: judges discriminate between the world of those who do know (how to lie) and the world of those who don't. With unwitting cynicism, the judges observed that the plaintiff had not been able to see a lawyer ${ }^{9}$, which to them came as a confirmation of 
his sincerity. Legal advice would have vitiated his testimony. The judge draws a very clear line among beings: the unblemished (and credible) on the one hand, the tainted (and inaudible) on the other. Applying to the legal field a terminology borrowed from the semiotics of science and technology, it could be said that the plaintiff can only be heard and credible if he/she conforms to a rock-hard "script" (Akrich, 1992), established by the judges and as uncompromising as the script of a metal detector, which either does or does not beep when walked through by a passenger (Jobard, Linhardt, 2008). Hence, the credibility of Selmouni's testimony rested neither on the clumsiness of the police nor on the outrageousness of the abuse he had been subjected to: both conditions, though necessary, were insufficient. His probative force was a product of his "common man" condition. Of his being hitherto untainted by any prior connections to the legal machine and the tricks it can teach you. Of his lack of penal attributes.

Whether the potential success of the alleged abuse narrative be described borrowing the script concept from the sociology of science and technology or the pure/impure dichotomy from anthropology (Douglas, 1966), a particularly exiguous space is being outlined wherein illegitimate policing abuse starts being considered as such by society ${ }^{10}$. While this is not the place to explore the particulars of its inception, we may nevertheless sketch out the area of admissibility of policing abuse as some kind of quadrilateral with interrelated vertices. The first vertex, as we have just seen, is that of penal purity. The second one relates to the magnitude of the abuse, which has to be remarkable. Third comes the evidence: whether material or testimonial, it is subject to the same purity requirements as the putative victim was. If witnesses are related to the victim in any way, or if they do not offer the guarantees required by the judicial script in terms of reliability or purity, then their word is discredited and cannot take advantage of any "operators of factuality" anymore (Dulong, 1997, 1998). At the fourth corner lies the context of the abuse. Converting an alleged fact into a recorded one implies establishing beyond doubt that the police acted without being in danger or threatened in any way. It should be noted here that this property of the quadrilateral is not devoid of policing intervention - in larger proportions than the others. In a report on disciplinary lapses within the Police Nationale, the Director of the IGPN (Inspection Générale de la Police Nationale ${ }^{11}$ ) noted that the yearly ratio of established facts fluctuated between $7 \%$ and $20 \%$ of alleged cases when the claimant himself was not targeted by a complaint from the police, and only $0.6 \%$ to $7 \%$ when the police had filed a complaint against the claimant. The Director then added:

\footnotetext{
Whenever the use of force is unnecessary or overwhelming, violence becomes illegitimate. It can then hide behind an accusation of verbal assault, unlawful rebellion or assaulting a police officer. At that stage, establishing the truth becomes difficult. (Le Doussal, 1988, 41)
}

Without venturing further into a detailed explanation of the constraints of converting an alleged fact into an established one, we observe that it is precisely in those social spaces where policing most tends to resort to force that this approach is least likely to trigger court action. Relegated urban areas feature such a high proportion of young males with prior convictions - and an even higher number of young males "known to law enforcement", with a police record for having been arrested at least once - that it is difficult to find witnesses with no penal record-or even "non-unclean" third parties, given the levels of social segregation in such areas (Lagrange, 2009). High tension areas, where the police are most likely to resort to forceful action, are those where policing abuse is the least likely to be brought to the spotlight. In such social spaces, silence and violence behave like both sides of one and 
the same Möbius strip.

Hence, the openness/secret duality which Brodeur considered to be an obstacle to his policing "theory" actually appears, in the empirical reality of the becoming of violent events, to be a component of policing. Far from behaving as an organism splitting into two separate organisms, high and low policing (Brodeur, 1983), policing is constitutively dual: open or secret, depending on the circumstances, place, or protagonists. The dirty, suspect, "tainted" side of policing, considered by Brodeur to be a hindrance to his theory of policing, affects both policing agents and the society in which they intervene. And since not all sections of society receive an even share of light, police actions, in turn, get uneven exposition to the public gaze.

And so, from a legal point of view, the concept of "openness" must be considered in its relation to publicity, as in "openness and publicity of proceedings" for instance, which guarantees equality of arms, etc. Justice is done when both parties get fair access to it, when charges, proofs, and motivations are made public; when, simply, the policing intervention is being "dramatized" (Manning, 2010, x), which enables the general public to act as a judge or, which amounts to the same, makes judges publicly accountable of how they judge ${ }^{12}$. Sociological studies on the use of force by policing agents, however, reveal that allegations of abuse tend to be received in an incredibly exiguous space; an unfair space, in fact, which prevents most allegations from ever crossing the threshold of publicity, for want of being heard or simply audible.

The publicity of policing, which touches both the demand for openness and the sad acknowledgment of the "tainted" side of the job, is a key issue for any theory of policing. Shadowy darkness, far from impeding the development of a theory of policing as Brodeur seemed to fear, is in fact the touchstone of a political theory of policing, as we are about to show.

\section{The place of sovereignty in the theory of policing}

It can be noted that in social spaces of relegation, where the need for policing is the most urgent, as long as deviant behaviors do not exceed certain limits (crude and obvious editing of charge sheets, blatant mistakes on the social identity of opponents, shooting of a handcuffed individual, etc.), police deviance will not be disciplined (regardless of the scale of disciplinary measures). Jean-Paul Brodeur's definition rests on an implicit continuum of policing means: authorized to use, in more or less controlled ways, diverse means [...].

This remark does not fit the empirical reality of how the police relate to the law. There is indeed such a thing as a deviant relationship to the law, which can be punished by a judge, just as there is such a thing as a form of lawlessness which shall not be punished, insofar as it is kept hidden from the judge's sight. In a certain way then, we end up with two types of policing. Not in the sense of two different policing institutions, such as high and low policing, and not in the sense of two antagonistic policing practices - the beat policeman vs. the undercover agent, for instance - but two "modalities" of policing, depending on the circumstances and social space wherein a given policing intervention takes place. There simply are specific social spaces where no appeal will ever be made against any policing intervention - where policing agents thus reign supreme. In such spaces or circumstances, policing institutions replace the law, prescribing the norms, with the understanding that no law can exist without punishment. Policing, in such spaces or circumstances, pertains 
to a decisionist theory of law whereby (as opposed to normativism) the law does not derive from some supreme norm (Constitution, Bill of Rights, Code...), but from the individual gesture of whoever decides with no risk of being disallowed. Here is how German jurist Carl Schmitt $(1934,20)$ formulated this decisionist theory of law:

Sovereign is he who decides on the exception.

This definition of sovereignty is twofold: sovereign is he whose decision cannot be appealed as long as it was made in exceptional circumstances; and sovereign also he who may decide that circumstances have become exceptional and ordinary laws cease to apply. The concept of "police discretion" (one of the oldest in the sociology of policing - see Klockars, 1985) is to be understood in the context of the latter acceptation, as illustrated by the bitter statement made 25 years ago by the then Director of IGPN (above), commenting on the possibility of post-hoc rewriting of any situation. Policing agents, in certain social spaces, are in a position to cut off access to the legal system for other parties, thus effectively switching to a regime of exception. In some specific arenas, the law is simply not the same.

This peculiar relationship of policing agents to sovereignty has various repercussions. The most obvious has to do with the State - i.e. public authorities: in certain social spaces or circumstances,"the exception reveals most clearly the essence of the state's authority" (Schmitt 1934, 19, trans. Schwab, 13). In such spaces or circumstances, legal standards per se no longer perform satisfactorily, and public authorities have to wield the sword of power to reach a decision that can only be final.

The most salient theoretical consequence of the decisionism revealed by the failure of criminal justice to act against legal lawlessness, however, does not pertain to state power but - understanding sovereignty in the sense conferred to it by Schmitt - to the relationship between policing and the political. Before tackling this dimension, however, we need to preemptively highlight the dangers inherent to applying the concept of sovereignty to policing agents, given the many absolutist conceptions bearing no relationship whatsoever with the reality of our current societies generated recently by Schmitt's decisionism.

\section{A sociological theory of policing (or: what a decisionist theory of policing is not)}

Our whole argument is based on the old, commonplace idea (Reiss, Bordua, 1967) that the various spaces that make up a society receive different types of policing. What is surprising is that the theoretical repercussions seem to have been overlooked, especially in terms of determining the right fit for law into policing. As emphasized by Pierre Favre (2010, 1237):
Social sciences are often reluctant to admit how decisive the very existence of policing forces - in the wider sense - is in perpetuating social order, and even more in producing it. Sociologists thus argue that order has now been internalized in advanced societies and that resorting to force has become unnecessary. While they rightly point out that violent policing interventions are the exception rather than the norm, this leads them to remove all traces of police use of force from their analyses.

When Brodeur proposed a legal lawlessness-centered definition of policing, he excluded from the scope of this definition the fact that the law, far from being universal, is and remains a socially exclusive asset - as if whatever dealt with a 
sociological analysis of the differential implementation of the law by policing agents (i.e. the sociology of "law enforcement", in the stricter sense, as engaged by Black, 1973) did pertain to a specific area of sociological investigation, but no longer had any relevance to the theory of policing. Brodeur observed that policing was fundamentally "selective" (Policing Web, 119), but such a consideration did nothing to alter his definition of policing, whose "completeness" he wanted to protect, knowing full well that it was being threatened by duality... Resorting to Schmitt's decisionism is not just the theoretical consequence of a concrete law-based approach of the sociology of policing: it also does justice to the duality and "tainted" nature of policing.

30 This decisionist theory has its own underlying social geography. Throughout most of society, policing agents are subjected to the shared law, which they can emancipate from only in some specific sections of said society. Hence, resorting to Schmitt - one of the jurists who sit at the very core of an ongoing scandal in intellectual history (Müller, 2003) - does not entail any intention to turn policing institutions into the vector of a new world order placed under the sign of the "permanent exception" or the dramatic tumbling of our societies into a new bio-political age marked by the triumph of sovereign power over the naked life, if we may thus bluntly summarize the exhausting ramblings produced over the last two decades by some Schmitt readers. It is not the world we are dealing with here, but a very tangible society with very tangible social designs; our challenge is indeed to produce a theory of policing anchored in the sociology of its practices (for a comparable approach, see Fischer, Spire, 2009, 13-14; note that my criticism of the "ramblings" quite concurs with Fischer, 2011).

Besides, sovereignty does not imply absolute power either. The practical powers of policing agents in areas of sovereignty remain enclosed within the bounds of the quadrilateral we have drawn above. The police still need to assess the nature of whoever they are facing, the likelihood of credible witnesses, and the magnitude of the damage they may inflict. Their sovereignty is being limited by the anticipated reception - by their colleagues, and then by the judges - of the post-intervention narrative they will be able to produce. This constraint severely restricts their latitude (Manning, 1978; Jobard, 2005), and constantly indexes policing action onto the nature of the environment in which a given policing intervention takes place. The police - these "streetcorner politicians", in the words of William Ker Muir (1977) are political actors insofar as, faced with an upcoming interaction, they have to assess what can or cannot be considered politically acceptable behavior from them (see a similar work by Josiah McHeyman on border patrol agents at the Mexico-US border, e.g. McHeyman, 2000). Policing agents, at the very moment of engaging into an interaction, are busy gauging the political mandate entrusted to them by the society. To be more precise, they are busy assessing whether or not the political conditions are met that would allow them to engage in an act of sovereignty, should they wish to do so.

32 This is how "police discretion", as put forward by North American sociologists for several decades, should be understood. Because one form of power exists that includes the use of force, possibly up to the infliction of death, and because one form of power exists that commands respect to all other forms of power in certain circumstances, then this discretionary form of power pertains to sovereignty: it is a political power. For, as suggested earlier, what is at stake here is not merely the substitution of the law by the pure power of the state, but the political in its very essence.

\section{A political theory of policing}


Empirical understanding of the fate of police-perpetrated acts of lawlessness enables us to delineate a space of sovereignty wherein policing agents may operate. What does such an insight entail? What is the added value of our observations? Are we simply replacing one concept (police discretion or legal lawlessness) with another (sovereignty)? The detour through Schmitt's decisionist theory appears to be decisive, inasmuch as the new perspectives it opens allow us to fit policing into the wider framework of "political theory", an area that embraces both the theory of justice championed by Rawls or Hart (see Manning, 2010) and the theory of the State or, in a broader sense, of the polity.

Interestingly - assuming anyone still needs to be convinced that policing should be studied as an element of the theory of the State -, in Pierre Bourdieu's lectures on the State, which have just been published in French (Bourdieu, 2012), policing, and more broadly coercion, have just vanished from the definition of the State, thanks to a clever conjuring trick. Surprisingly in such a context, the word "police" simply does not appear in the table of contents of the 660-page compendium; and out of the grand total of nine occurrences in the whole book, most consist in a metonymic use of the term, encompassing the whole repressive apparatus of the State and casually quoted in the vicinity of such terms as "army" or "all institutions whose mandate is to guarantee law and order" (l'ensemble des institutions mandatées pour garantir l'ordre; 22, 215, 239, 315, 327). Here is a sample of how the dissimulation of physical force and policing in today's polity is being carried out:

\begin{abstract}
Several years have passed already since I added to Max Weber's famous definition of the State as "the monopoly on legitimate violence", which I amended and augmented as a "monopoly on physical and symbolic violence"; one could even say: "monopoly on symbolic legitimate violence", insofar as the monopoly on symbolic violence is the condition for possessing the right to exercise the monopoly on physical violence itself. (Bourdieu 2012, 14)
\end{abstract}

If, however, one unwinds the thread of legal lawlessness to the very end, as is my claim here, to discover the notion of sovereignty, it appears quite clearly that what is at stake is more than physical violence as a mere appendage of "symbolic violence". For what the concept of sovereignty as supported by daily policing action leads to is a deeper understanding of the political dimension of policing. Most authors, following Bittner, have put physical force at the core of their conception of policing. Some, like Brodeur, have built an entire model around lawlessness. Very few - Manning is one - have relied on the concept of exception as a major aspect of the definition of policing. And when they did, they proved reluctant to fully open the ensuing theoretical perspective. ${ }^{13}$ Which perspectives, then, get unlocked when resorting to this concept?

To Schmitt, making decisions in an exceptional situation (i.e. exercising sovereignty) amounts to expressing the political; in other words, in Schmitt's idea, to distinguishing between friend and foe. For the product of sovereign decision-making is not so much the State as the political itself. The State is but a specific shape, self-engineered by the "political unit" - the polity - in the course of performing sovereign decision-making itself. The famous statement says it all: the concept of the state presupposes the concept of the political (Schmitt, 1934, 20, trans. Schwab); and the political as well as the polity are defined by this peculiar moment when friend is separated from foe $(1934,22$; trans. Schwab: the specific political distinction to which political actions and motives can be reduced is that between friend and enemy, 26). Decision-making in an exceptional situation is the particularly intense moment when the political manifests itself, and this manifestation is the channel through which a community, a society, identifies its own enemy. According to this interpretation, which is based on the first pages of Schmitt's The Concept of the 
Political, the policing body, insofar as it enjoys spaces of sovereignty conceded by the political system, is this entity which, in our rational-legal societies, takes on the responsibility of defining the enemy; a day-to-day (as opposed to the Army or even criminal justice) institution in charge of perpetuating, within the rational-legal State, the normative order of procedure described by Max Weber (Colliot-Thélène, 2009), a State defined in its substance - in this particular case, by its ability to designate an enemy within the community. The sovereign act established by the police is, in the impacted social spaces, the gesture whereby policing turns an indistinct assemblage into a political community, i.e. a polity.

At that stage of formulating our hypothesis, we should refrain from any absolutist interpretation of the concept of enemy. Schmitt apparently relied on a rather procedural, if not tautological conception of it: devoid of prior essence, the enemy is whoever happens to be considered as such. In his use of the term, Schmitt picked up (and subverted - see Kervégan, 1992, 186) on an idea once used by Hegel to establish the political community. Hegel has also advanced a definition of the enemy, which in general has been evaded by modern philosophers. The enemy is the ethical difference (die sittliche Differenz), as the alien to be negativized in his living totality (1996, 62 - pers. translation from Der Feind ist die sittliche Differenz, als ein zu negierendes Fremdes in seiner lebendigen Totalität). It would be anachronistic to take Schmitt's Fremd to mean "foreigner" in the modern nation-state sense, as someone who, although present on the national territory, is in fact endowed with a different citizenship. Rather, he is the stranger, or the other. In Hegel's view then, the stranger is whoever does not partake to the ethics of the community, its shared values... simply put, its mores (die Sitten). According to this argument, modern policing agents, in whatever spaces of sovereignty are granted to them, are expected to control the undisciplined, those whose mores take exception - or are supposed to take exception - from the dominant ones. As Didier Fassin $(2011,314)$ put it in his recent ethnography of a police force, these are "enemies" (his term), defined as such because of their being "rejected in a radical otherness"14.

Seizing whatever crops up when taking seriously the idea that legal lawlessness lies at the very core of the concept of policing - i.e. when examining the tangible manifestations of this particular brand of lawlessness - thus unfolds a substantial dimension of policing: the dimension of the political, of ethical otherness which, at some specific stage of its development, defines the limits and nature of the polity. As if, somewhere below the rational-legal State, policing agents were busily engaged in perpetuating its substantial, irreducibly political dimension - which, in all likelihood, does explain their irreducible violence indeed. Assessing the whole range of theoretical consequences stemming from the definition proposed by Jean-Paul Brodeur in Policing Web, however, would take us far beyond the scope of this tribute - which we now have to bring to a conclusion.

\section{Conclusion}

There can be little doubt that with such concepts as the polity, sovereignty or the enemy, even the most empirical (not to say empiricist) research on policing would hinge a lot better onto various areas of political theory than is currently the case assuming proponents of said research were actually willing to relate to any theory at all. In particular, the bulk of cumulated research on the relationship between the "racial/minority threat" and policing, which tends to suggest that the degree of policing (as per the number of police officers or the funding of police departments) is somehow indexed to the number of Black people in a given city, would most likely 
find promising theoretical opportunities here.

Let us keep in mind, however, that on-principle racializing of the enemy would oversimplify the problem, stifling its heuristic dimension. In this respect, the rejection of any Schmittian dimension of policing by Jean-Paul Brodeur and his colleague Egon Bittner, with whom he maintained highly fecund exchanges, is somewhat disconcerting. Below is an excerpt of what Bittner said in the course of these exchanges:

Finally, I want to disregard the very influential formulation of the function of the state by Carl Schmitt, namely that the state is defined by the presence of its enemies. And now, what is left is essentially what was present already in the city of antiquity. That is, it's a polis that already redefines the minimal state, where it literally consists of the organization of conditions of urban life. (...) What then the state provides in its minimal function is creating conditions for the orderly coexistence of strangers. (Bittner, in Brodeur, 2007, 111)

A somewhat puzzling passage insofar as it clearly appears that Egon Bittner (with the obvious approbation of his interlocutor) refuses to grant policing its real status in the constitution of polities. Certainly, as Bittner himself says, policing agents are in charge of the internal order of the city, which consists in the orderly coexistence of strangers. Again, not "foreigners" originating from different nations or countries, but "strangers" in the sense that their mores do not concur, which requires one of the groups to enforce some discipline, some shared ethics to allow for a harmonious life in a shared urban environment. Hence, those who contribute, through the sovereign acts of policing, to building the polity, are neither the Blacks, the foreigners or the North Africans, but the men without roots (Emsley 2007, 43), the assholes (Van Maanen, 1978), and more tautologically the police property (Lee, 1981). Discipline enforced at their expense (Choongh, 1997) is the ever-renewed founding act of the political community. Again, policing authorities are sole judges of the political mandate they are entrusted with, which is subject to change as the society itself changes. A case in point is the "gay hunt" activities of the "Morals division" of the New York Police Department... which sparked the Stonewall movement and eventually led to a complete reversal of the political mandate regarding the status of gay people in the political community. Conversely, only after decades of indifference were the staff of the Los Angeles Police Department being told that their enemy was Mexican migrants, which ultimately, year after year, contributed to building the political identity of these migrants within the political community in the USA, or at least in California (Escobar, 1999). The political mandate translates into action via the economy of force or restraint, as assessed or even pondered by the police during the interaction (similarly, see Favre, 2010, 1241-43).

Jean-Paul Brodeur does not say otherwise in his given definition of policing: to enforce various types of rules and customs that promote a defined order in society. We would say that it has as much to do with defining a public order (a set of shared rules and regulations) as with contributing to a substantial definition of the political. Indeed, this is what makes policing as an institution so controversial, in the stronger sense: it is located at the heart of the political. This is also what makes any attempt at amending or reforming it such a difficult task: what role can policing agents assume if not that of controlling and civilizing the fringe of social order?

Still, it should be remembered that carrying out acts of sovereignty (in the sense defined above) does not exempt the police from respecting some rules. Quite the opposite: they are rather enmeshed in various constraints pertaining to the nature of their interlocutor, the nature of the location or of the crowd, but also to the circumstances and the political context-whatever is happening in politics at the moment. Far from being a given, police discretion is constantly being assessed during action by the police themselves, who evaluate what the political community is liable to either endorse, or reject as no longer constituting legal lawlessness, but pure 
departure from the law. The political mandate conferred to policing authorities is not an intangible given; it gets tested by the police with each of the interactions they undertake.

Hence - endorsing, after Jean-Paul, Egon Bittner's definition of policing - we would say (emphasis added on differences):

The role of the police is best understood as a mechanism for the distribution of non-negotiable means employed in accordance with the dictates of an intuitive grasp of political exigencies.

Where "political" refers to both the police assessing the scope of the mandate entrusted to them by the community, and the structuring, substantial effect of their action proper on the nature and boundaries of the polity. As can be seen, policing has little to do with mere civility, it is of a different order altogether, touching the very foundations of our political societies - as if policing authorities had somehow inherited the political mandate of offsetting both the cold rationality of the State and the burden of a disenchanted world.

\section{Bibliographie}

Akrich M., 1992, The de-scription of technical objects, in Bijker W., Law J. (Eds), Shaping Technology/Building Society, Cambridge, MIT Press, 205-224.

Anderson M., 2011, In Thrall to Political Change: Police and Gendarmerie in France, Oxford, Oxford University Press.

Bittner E., 2001, Florence Nightingale à la poursuite de Willie Sutton, Déviance et Société, 25, 3, 285-306 (trad. de l'article paru en 1974, in Jacob (dir.), 1974, The Potential for Reform of Criminal Justice).

Bittner E., Brodeur J.-P., Jobard F., Lévy R., 2001, Débat. Autour de Bittner, Déviance et Société, 25, 3, 279-345.

Black D., 1973, The Mobilization of Law, The Journal of Legal Studies, 2, 1, 125-149.

Bourdieu P., 2012, Sur l'État. Cours au Collège de France. 1989-92, Paris, Seuil.

Brodeur J.-P., (ed.), 1983, High and Low Policing. Remarks on the Policing of Political Activities, Social Problems, 30, 5, 507-520 (revised and updated version in La police politique. La haute police, in Les visages de la police. Pratiques et perceptions, Montréal, Presses universitaires de Montréal, 2003, 225-254).

Brodeur J.-P., (dir.), 2005, La police en pièces détachées, Criminologie, 38, 2, 3-172.

Brodeur J.-P., 2011, The Policing Web, Oxford, Oxford University Press.

Brodeur J.-P., 2008, Que dire maintenant de la police ?, in Monjardet D., Chauvenet A., Ocqueteau F., (dir.), Notes inédites sur les choses policières (1999-2006), Paris, La Découverte, 255-268.

Brodeur J.-P., 2008, Haute et basse police après le 11 septembre, Criminologie, 41, 1, 133-151 (repris in Jean-Paul Brodeur d'hier à aujourd'hui, numéro spécial de Criminologie, 44, 1, 2011, p. 225-245, présentation F. Ocqueteau).

Bugnon G., 2011, Le constat médical peut-il mettre à l'épreuve les frontières de la force policière légitime? Enquête sur un dispositif médico-légal de dépistage des violences policières, Déviance et Société, 35, 1, 113-136.

Cahn O., 2007, Actualité de l'arrêt R. v. Secretary of State for the Home Department ex parte Ramda du 27 juin 2002 : incident isolé ou précédent dommageable ? Cultures \& Conflits, 66, 121-156.

Choongh S., 1997, Policing as social discipline, Oxford, Clarendon Press.

Colliot-Thélène C., 1999, Carl Schmitt versus Max Weber: Juridical Rationality and Economic Rationality, in Mouffe Ch., The Challenge of Carl Schmitt, Londres, Verso Books.

Colliot-Thélène C., 2009, Modern rationalities of the political. From Foucault to Weber, Max Weber Studies, 9, 1-2, 165-187.

Cornevin Ch., 2010, Plus de 3100 policiers sanctionnés en 2009, Le Figaro, 16 juillet.

Douglas M., 1966, Purity and Danger. An Analysis of Concept of Pollution and Taboo,Londres, Routledge \& Kegan Paul. 
Dulong R., 1997, Les opérateurs de factualité. Les ingrédients matériels et affectuels de l'évidence historique, Politix, 10, 39, 65-85.

Dulong R., 1998, Le témoin oculaire. Les conditions sociales de l'attestation personnelle, Paris, Éditions de l'EHESS.

Emsley C., 2007, Crime, police, and penal policy: European Experiences 1750-1940, Oxford, Oxford University Press.

Escobar E.J., 1999, Race, police, and the making of a political identity: Mexican Americans and the Los Angeles Police Department, 19oo-1945, Berkeley, University of California Press.

Fassin D., 2011, La force de l'ordre. Une anthropologie de la police des quartiers, Paris, Seuil.

Favre P., 2010, Quand la police fabrique l'ordre social. Un en-deçà des politiques publiques de la police ? Revue française de science politique, 59, 6, 1231-1250.

Fischer N., 2011, "Guerre aux migrants ? ». Le modèle du camp à l'épreuve de l'économie du maintien de l'ordre et de la subversion en rétention administrative, contribution au XIe Congrès de l'Association Française de Science Politique, Strasbourg, section thématique $\mathrm{n}^{\circ} 9$. Section thématique 9, « Ni guerre, ni paix : enquêtes sur les ordres politiques disloqués ».

Fischer N., Spire A., 2009, L'État face aux illégalismes, Politix, 22, 3, 7-20.

Hodgson J., 2002, Suspects, defendants and victims in the French criminal process. The context of recent reform, International and Comparative Law Quarterly, 51, 4, 781-816.

Jobard F., 2003, Raw facts and narratives, Policing and Society, 13, 4, 423-428.

Jobard F., 2005, Le nouveau mandat policier. Faire la police dans les zones dites 'de non-droit', Criminologie, 38, 2, 103-121.

Jobard F., Linhardt D., 2008, Control and guardianship. A comparison between two surveillance spaces, Orly international airport and Dammarie's housing project, in Deflem M. (Ed.), Surveillance and Governance. Crime Control and Beyond, Bingley, Emerald Pbg/JAI Press, 77-102.

Klockars C.B., 1985, The Idea of Police, California, Sage Publications Beverly Hills.

Ker Muir W., 1977, Police. Streetcorner Politicians,Chicago, Chicago University Press.

Kervégan J.-F., 1992, Hegel, Carl Schmitt. Le politique entre spéculation et positivité, Paris, Presses universitaires de France.

Krynen J., 2012, L'état de justice. France, XIIIe-XXe siècles, Paris, Gallimard, vol. 2.

Lagrange H., 2009, The French riots and segregation, in Waddington D., Jobard F., King M. (Eds), Rioting in the UK and France. A Comparative Analysis, Cullompton, Wilan, 107-123.

Le Doussal P., 1988, Étude sur les fautes disciplinaires, Paris, IGPN, ministère de l'Intérieur.

Lee J., 1981, Some structural aspects of police deviance in relations with minority groups, in Shearing C., Stenning Ph. (Eds), Organizational Police Deviance. Its Structureand Control, Toronto, Butterworths, 49-82.

Manning P.K., 1977, Rules, Colleagues, and Situationally Justified Actions, in Manning P.K., Van Maanen J. (Eds), Policing. A View from the Street, New York, Random House, 71-88.

Manning P.K., 2003, Policing Contingencies, Chicago, University of Chicago Press.

Manning P.K., 2010, Democratic policing in a changing world, Boulder, Paradigm Publishers.

McHeyman, J.M.C., 2000. Respect for outsiders? Respect for the law? The moral evaluation of high scale issues by US immigration officers, Journal of the Royal Anthropological Institute, 6, 4, 635-652.

Moreau de Bellaing C., 2009, Violences illégitimes et publicité de l'action policière, Politix, 22, $3,119-141$.

Müller J.W., 2003, A Dangerous Mind. Carl Schmitt in Post-War European Thought, Yale, Yale University Press.

Ocqueteau F., 2004, Polices entre État et marché, Paris, Presses de Sciences Po.

Reiner R., 1992, The Politics of the Police, Toronto, Toronto University Press, $2 \mathrm{~d}$ ed.

Reiss A.J., Bordua D.J., 1967, Environment and Organization. A Perspective on the Police, in Bordua D.J. (Ed.), The Police. Six Sociological Essays, New York, John Wiley \& Sons, 25-54.

Rodley N., 2005, Torture, Violence, and the Global War on Terror, American Society of International Law Proceedings, 99, 402-407.

Salvy E., 2012, MPs table questions over French 'President's Spy' revelations, Mediapart, 26 janvier.

Schmitt C., 1932, Der Begriff des Politischen, Berlin, Duncker \& Humblot (trad. angl. : The Concept of the Political, transl. G. Schwab, Chicago, Chicago University Press, 2007). 
Schmitt C., 1934, Politische Theologie. Vier Kapitel zur Lehre von der Souveränität, Berlin, Duncker \& Humblot (trad. gb : Political Theology. Four Chapters on the Concept of Sovereignty, transl. G. Schwab, Cambridge, MIT Press).

Skogan W.G., Frydl K., 2004, Fairness and Effectiveness in Policing. The evidence, Washington, The National Academies Press.

Stenning Ph., 200o, Evaluating Police Complaints Legislation. A Suggested Framework, in Goldsmith A., Lewis C. (Eds), Civilian Oversight of Policing. Governance, Democracy and Human Rights, Oxford, Hart, 147-163.

Uildriks N., 1999, Police torture in France, Netherlands Quarterly of Human Rights, 17, 4, 411-423.

Van Maanen J., 1978, The asshole, in Manning P., Van Maanen J. (Eds), Policing. A view from the street, New York, Random House, 221-237.

Willsher K., 2011, French intelligence chief accused of spying on journalist, The Guardian, 10 octobre.

\section{Notes}

1 See, in Déviance et Société (2001, René Lévy ed.), the special feature on Egon Bittner's contribution to the sociology of policing, as well as the invitation extended by Jean-Paul to several young French scholars, including yours truly, to contribute to the Anniversary issue of Canadian journal Criminologie (2005), commemorating the famous 1984 issue on policing edited by Jean-Paul himself.

2 For the benefit of foreign readers who may not be familiar with recent French developments in the field, here is a brief compendium of January 2012 national headlines (bearing in mind that no less than 14 police and gendarmerie personnel have been reported by the national press as killed on duty in 2011): the demise of Wissan El-Yamni, a 30-year-old man who appears to have been choked to death while being arrested; the acquittal, by a criminal court in Nice, of 4 policemen accused of having raped a prostitute; the confirmation, by an administrative court, of the compulsory retirement of a police officer who had disclosed the police files of two French celebrities, in a move to protest the very existence of such files (which he considered an infringement on civil liberties); the suspension of the prison sentence pronounced in 2011 against several police officers who had, on the basis of forged evidence, accused a man of attempted murder against a policeman; and the rally called by a police union organization to protest a commemorative plate that a suburban city council in the greater Paris area planned to put up in remembrance of 69-year-old Ali Ziri, who died in custody at the local police station.

3 Our French-language "translation" is a deliberate "treason" whose purpose is to associate the term to Foucault's heritage. According to Michel Foucault, lawlessness, as exemplified by tax evasion, is a form of law avoidance needed by the social order to perpetuate itself: "Lawlessness is no accident or imperfection. It is an absolutely positive element of social functioning. Legislation always provides protected, profitables spaces where the law may be violated, others where it may be ignored, and others still where violations are punished." (Foucault, 1976, quoted in Fischer, Spire 2009, 86, our translation). Strangely enough, Brodeur makes almost no reference whatsoever to Foucault in Policing Web.

4 The use of the present participle "policing", along with the plural form of "agents", helped convey the multiplicity of actors and actions: In line with my inventory of persons professionally involved in policing, I prefer the expression 'policing agent' to the word 'police' which generally refers to public constabularies. (Policing Web, 130). See how this present participle was introduced in Ocqueteau's [French-language] discourse (Ocqueteau, 2004, 50).

5 In fact, Jean-Paul Brodeur's prestige in the Anglo-Saxon world was largely based on his promoting this twofold definition of policing, the "high" and the "low" (Brodeur, 1983/2003, 2008/2011).

6 Again, facts abound in recent French news (Willsher, 2011; Salvy, 2012).

7 See, more generally, how judges tend to "create" the law depending on their own perception of whether society's expectations are being met or not (Krynen, 2012, 210).

8 On the insufficiency of medical certificates per se, see (in the French context) the recent empirical demonstration in Bugnon, 2011, as well as several remarks in Moreau de Bellaing, 2009, 87-89 in particular.

9 As opposed to what has long been the case in common-law procedure, French law did not provide for the presence of a legal counsel during police custody, at least until the Code of Criminal Procedure was reformed in January 1993 (Hodgson, 2002) a reform that was actually triggered by several deaths in police custody, just like the 15 June, 2000 Act that subsequently complemented it was partly a consequence of the condemnation of France in the Selmouni 
case.

10 For a similar demonstration drawing on disciplinary action files from the Paris police force, see Moreau de Bellaing, 2009.

11 The IGPN is the French police overseeing body and public complaints authority (Anderson, 2011, 395). Despite having been commissioned by the then Minister of Interior, the report remained unpublished.

12 According to the Director of the IGPN, the police are at the receiving end of $50 \%$ of all disciplinary action against civil servants in France, when they only account for $8 \%$ of the entire civil service staff (Boyajean in Cornevin, 2010). From this perspective, the police are subject to strict control indeed. However, this administrative, disciplinary, or even collegial channel for the settlement of deviances is one thing, and public justice of the public force quite another (Stenning, 2000).

13 Peter K. Manning (2003, and most importantly 2010, 68) offers a multidimensional definition of policing, mentioning the exception as a vanishing point: "The police as an organization in Anglo-American societies, constituted of many diverse agencies, are authoritatively coordinated, legitimate organizations. They stand ready to apply force, up and including fatal force, in politically defined territories. They seek to sustain politically defined order and ordering via tracking, surveillance and arrest. As such, they require compliance to command from lower personnel and citizens and the ability to proceed by exception. While politics is clearly key in this definition (which makes it quite unique), the exception is more of a vanishing point than a touchstone for the concept of policing. Manning only devotes eight lines to this notion, emphasizing that this dimension "has not been well explored, although political theorists, notably Carl Schmitt, have written about the importance of 'exceptionalism' in the face of crises (Manning, 2010, 79-80).

14 It should be noted that this ethnography, which draws on the concept of the exception ("a small state of exception"), linking it to Walter Benjamin (Fassin, 2011, 330), aims to offer an "anthropology of the State", in a perspective that has more to do with the postcolonial dimension of the action of the State than with the theory of the State per se.

\section{Pour citer cet article}

Référence électronique

Fabien Jobard, «Proposition on the theory of policing », Champ pénal/Penal field [En ligne], Vol. IX | 2012, mis en ligne le 12 mai 2012, Consulté le 22 octobre 2012. URL :

http://champpenal.revues.org/8286 ; DOI : 10.4000/champpenal.8286

\section{Auteur}

Fabien Jobard

Director of CESDIP (UMR 8183, CNRS/UVSQ/M. de la Justice).

Contact: fabjob@cesdip.fr

Articles du même auteur

Propositions sur la théorie de la police [Texte intégral]

Paru dans Champ pénal/Penal field, Vol. IX | 2012

\section{Droits d'auteur}

(C) Champ pénal 